\title{
VÝVOJ MEZD V JEDNOTLIVÝCH KRAJICH ČESKÉ REPUBLIKY S DŮRAZEM NA KRAJ MORAVSKOSLEZSKÝ
}

\section{DEVELOPMENT OF WAGES IN INDIVIDUAL REGIONS OF THE CZECH REPUBLIC WITH THE EMPHASIS ON THE MORAVIAN- SILESIAN REGION}

\author{
ING. KARIN GAJDOVÁ \\ DOC. Ing. Pavel TULEJA, Ph.D. \\ Katedra ekonomie $\mid$ Department of Economics \\ Obchodně podnikatelská fakulta v Karviné School of Business Administration in Karvina \\ Slezská univerzita v Opavě Silesian University in Opava \\ $\triangle$ Univerzitni nám. 1934/3, 73340 Karviná, Czech Republic \\ E-mail: gajdova@opf.slu.cz,tuleja@opf.slu.cz
}

\begin{abstract}
Anotace
Mezi nejdůležitějši faktory ovlivňujici fungováni ekonomiky se radí mzdy. Právě problematikou mezd se tento článek zabývá poněkud podrobněji. V úvodni části přispěvku jsou shrnuta důležitá teoretická východiska k celé problematice. Následuje část empirická, která je rozdèlena do dvou fází. Nejprve došlo pomoci komparativni analýzy ke srovnáni mzdových úrovni na územnich jednotkách České republiky NUTS 3. Dalši část př́spěvku je zaměřena na kraj, který je považován za jednu z největšich prümyslových oblastí v České republice, tedy na kraj Moravskoslezský.

Kličcová slova

průměrná hrubá měsični mzda, NUTS 3, průměrné tempo růstu, Moravskoslezský kraj

\section{Annotation}

The wages are the most important factors which influences the economy. This paper focuses on the detail of the issue of wages. The introductory part of this paper summarizes the important theoretical basis. Further there is the empirical part which is divided into two parts. First there is the comparison of wage levels in the territorial units NUTS 3 in the Czech Republic. Another part of the paper focuses on the region, which is considered one of the largest industrial areas in the Czech Republic. It is the Moravian-Silesian Region.
\end{abstract}

Key words

average gross monthly wage, NUTS 3, average growth rate, Moravian-Silesian region

JEL classification: $J 31, R 23$

\section{Úvod}

Rozvoj jednotlivých regionů v České republice není homogenní, mezi jednotlivými regiony vznikají disparity, a to z pohledu ekonomických, sociálních, ekologických, kulturních a jiných charakteristik. Jedním z důležitých ekonomických ukazatelů, ve kterých $\mathrm{k}$ regionálním disparitám dochází, jsou mzdy. V reálně fungující ekonomice je vývoj nominálních mezd považován za jeden z významných indikátorů ukazujících na „Zdravi“ příslušné ekonomiky. V rámci tohoto príspěvku jsme se rozhodli problematice mezd věnovat bližší pozornost. 
Po shrnutí důležitých teoretických východisek následuje část empirická, kdy dochází k srovnání mezd na úrovni územních jednotek NUTS 3 České republiky. V poslední části př́spěvku je uvedena analýza, která se podrobněji zabývá mzdami $\mathrm{v}$ jednom konkrétním kraji a to $\mathrm{v}$ kraji Moravskoslezském.

\section{Mzdy z pohledu ekonomické teorie}

V tržní ekonomice zabezpečuje koordinaci a užívání vzácných zdrojů trh. Mezi tyto trhy řadíme i trh práce, jenž se však vyznačuje určitými zvláštnostmi, které jsou dány specifickým postavením výrobních faktorů a obzvláště pak výrobního faktoru práce. Práce totiž neexistuje sama o sobě. Je konána lidmi, kteř́ jsou nositelé schopnosti pracovat. Vlastník tohoto faktoru tak na trhu práce sjednává jeho koupi, za cenu, již označujeme pojmem je mzda. Výše této ceny pak závisí, tak jako na jiných trzích, na působení nabídky a poptávky. (Fuchs K. a Tuleja P., 2003)

Poptávku po práci odvozujeme od poptávky po finálních výrobcích, z čehož vyplývá, že tato poptávka je poptávkou odvozenou. Samotná výše poptávky pak závisí na kvalitě vstupů práce, na množství a kvalitě kooperujících výrobních faktorů a na úrovni a užití technických a technologických znalostí. Kvalita vstupů práce je dána gramotností, vzděláním, odbornou průpravou a dovednostmi zaměstnanců. (Samuelson P. A. a Nordhaus W. D., 1991) Při nabízení práce se nejedná o rozhodování člověka mezi jednou nebo druhou činností. Zde jde o rozhodnutí, zda pracovat či nepracovat. Je třeba si tedy uvědomit, co tyto dvě varianty člověku přináší. Práce člověku přináší mzdu. Když ale nepracuje, získává tak volný čas. (Holman R., 2005)

Dá se tedy říci, že v reálně fungující ekonomice je vývoj nominálních mezd považován za jeden z významných indikátorů ukazujících na "zdravi““ příslušné ekonomiky. Z tohoto důvodu, jsme se $\mathrm{v}$ rámci této stati rozhodli problematice mezd věnovat bližší pozornost. Než se však dostaneme k vlastní analýze, jeví se nám jako vhodné připomenout co pod pojmem nominální mzda ekonomická teorie rozumí. Vyjdeme-li z dostupné literatury, pak můžeme nominální mzdu definovat jako peněžní odměnu vyplacenou za pracovní výkon vymezený dohodou mezi zaměstnavatelem a pracovníkem. Součástí takto definované mzdy tedy nejsou ostatní osobní náklady. Do mezd jsou tedy zahrnovány základní mzdy a platy, př́ílatky a doplatky ke mzdě nebo platu, prémie a odměny, náhrady mezd a platů, odměny za pracovní pohotovost a jiné složky mzdy nebo platu, které byly v daném období zaměstnancům zúčtovány $\mathrm{k}$ výplatě. Takto definované mzdy zpravidla označujeme jako mzdy hrubé, tj. mzdy, které nejsou sníženy o pojistné na všeobecné zdravotní pojištění a sociální zabezpečení, zálohové splátky daně z př́jmů fyzických osob a další zákonné nebo se zaměstnancem dohodnuté srážky.

$\mathrm{V}$ rámci námi realizované analýzy budeme posuzovat také dynamiku růstu průměrných nominálních mezd, a to pomocí ukazatele tempo růstu nominálních mezd $\left(\mathrm{g}_{\mathrm{w} ; \mathrm{n}}\right)$, jenž vyjadřuje procentní změnu nominální mzdy $\left(\mathrm{w}_{\mathrm{n}}\right)$ ve srovnání s předchozím obdobím:

$$
g_{w ; n}=\frac{w_{n ; t}-w_{n ; t-1}}{w_{n ; t-1}} * 100
$$

Kromě ukazatele budeme $\mathrm{v}$ rámci naší analýzy sledovat také průměrné tempo růstu nominálních mezd, přičemž $\mathrm{v}$ tomto př́padě budeme finální hodnotu určovat pomocí geometrického průměru jednotlivých meziročních temp růstu:

$$
G\left(g_{w ; 1}, g_{w ; 2}, \ldots, g_{w ; n}\right)=\sqrt[n]{g_{w ; 1}, g_{w ; 2}, \ldots, g_{w ; n}}=\left(\prod_{i=1}^{n} g_{w ; i}\right)^{\frac{1}{n}}
$$

Data, která pro potřeby naší analýzy využijeme, budou získávána z oficiálních zdrojů Českého statistického úrúadu a zaměřena na podnikatelskou sféru. Základní rozlišovací úrovní pak pro nás bude, vzhledem k našemu zaměření na nalezení regionálních rozdílů ve mzdách (touto problematikou se 
také zabývá Tvrdoň M., 2008), územní jednotka NUTS3, která v př́ípadě České republiky odpovídá jednotlivým krajům.

\section{Mzdy z pohledu jednotlivých krajů České republiky}

Z údajů zachycených $\mathrm{v}$ tabulce 1 zcela jednoznačně vyplývá, že v průběhu námi analyzovaných deseti let dosahovala v České republice hrubá měsíční mzda průměrné hodnoty 21.970 Kč. Pokud tuto částku porovnáme s průměrnými mzdami v jednotlivých nomenklaturních územních jednotkách, pak dospějeme $\mathrm{k}$ závěru, že $\mathrm{v}$ letech 2002-2011 se v České republice vytvořily v podstatě pět skupiny krajů, které bychom mohli označit jako (1) kraje s extrémně vysokou mzdou (Hl. m. Praha), (2) kraje s vysokou mzdou (Středočeský kraj), (3) kraje s průměrnou mzdou (Plzeňský a Jihomoravský kraj), (4) kraje s mírně podprůměrnou mzdou (Liberecký, Ústecký a Moravskoslezský kraj) a (5) kraje s výrazně podprůměrnou mzdou (Olomoucký, Královehradecký, Pardubický, Zlínský a Jihočeský kraj, kraj Vysočina a Karlovarský kraj). Výsadní postavení Hl. m. Prahy, a de facto i Středočeského kraje, je dáno především hospodářským postavením těchto regionů v rámci celé České republiky, kdy zejména v hlavním městě Praze má faktické sídlo velká část firem a významných institucí pưsobících na území celé České republiky (Nevima, J. a Ramik J., 2010), což se následně odráží také ve vyšším mzdovém ohodnocení těchto pracovníků. Středočeský kraj v případě vyšších mezd výrazně „těži“ ze svých př́mých hospodářských vazeb na Hl. m. Prahu, pro niž je významným zdrojem pracovních sil.

Podíváme-li se na opačný konec našeho fiktivního pořadí, zjistíme, že krajem s dlouhodobě nejnižší průměrnou mzdou je Karlovarský kraj (v námi stanoveném pomyslném pořadí obsadil průměrné 11,5 místo), který dosáhl nejnižší průměrné hrubé měsíční mzdy jak v letech 2005, 2010 a 2011, tak $\mathrm{v}$ př́ípadě desetiletého průměru. Také v tomto př́ípadě bychom mohli říci, že výše mezd úzce souvisí s ekonomickou výkonností tohoto regionu a z ní vyplývajícího postavení v rámci všech čtrnácti regionů České republiky. Dá se říci, že v podobně špatném postavení jako Karlovarský kraj se v rámci celého Česka nachází také kraje Vysočina (průměrná pozice 11,6 a dvakrát nejnižší mzda), Pardubický (11,4 a dvakrát nejnižší mzda), Jihočeský (11,1 a jedenkrát nejnižší) a Zlínský (11,0 a dvakrát nejnižší mzda), přičemž zejména u posledně jmenovaného kraje můžeme vysledovat poměrně negativní vývoj, když tento region „propadl““ ze 6. místa v roce 2005 na samý „chvost“ našeho pořadí, když v posledních čtyřech letech námi analyzovaného období dosahoval nejnižší, resp. druhé nejnižší průměrné hrubé měsíční mzdy.

Pokud opustíme analýzu absolutních ukazatelů a podíváme se na vývoj hrubých měsíčních mezd z hlediska jejich dynamiky růstu, pak zjistíme, že nejvyššího průměrného tempa růstu dosahovaly v námi analyzovaném období hrubé mzdy v Jihomoravském kraji, a to 4,11\%. Jihomoravský kraj je tak jediným krajem, $v$ němž tempo růstu průměrných hrubých mezd překročilo čtyři procenta. $\mathrm{Na}$ pomyslnou druhou a třetí pozici mezi kraji České republiky dosáhly kraje Vysočina a Pardubický, tj. regiony, které jsme v předchozí části textu zahrnuli do skupiny krajů $\mathrm{s}$ výrazně podprůměrnou mzdou. Kromě těchto tř́ krajů se nad celorepublikovým průměrem v letech 2002-2011 pohybovaly také kraje Středočeský a Moravskoslezský.

Naopak krajem s nejnižším průměrným tempem růstu nominálních mezd byl v námi analyzovaných deseti letech kraj Karlovarský, tj. kraj s nejnižšími průměrnými mzdami. Tento závěr je poněkud překvapivý, nebot' by se dalo očekávat, že právě kraj s nejnižším základem by měl být tím, který se bude $\mathrm{z}$ hlediska dynamiky růstu pohybovat spíše v první polovině pomyslného pořadí, jako tomu je $v$ př́padě krajů Pardubického a Vysočina. $Z$ výše uvedeného můžeme tedy učinit závěr, $z$ nějž vyplývá, že v př́ípadě Karlovarského kraje docházelo v letech 2002-2011 spíše k prohlubování mzdových disparit, když průměrné tempo růstu zaostávalo za celorepublikovým průměrem o $0,78 \mathrm{p}$. b. Zatímco v Česku průměrné hrubé měsíční mzdy v průběhu deseti let kumulovaně vzrostly o více než $1 / 3(34,57 \%)$, v př́padě Karlovarského kraje byl tento růst pouhých $26,91 \%$, díky čemuž tento region jako jediný nepřekročil hranici $30 \mathrm{p}$. b. Druhé nejnižší dynamiky růstu pak ve sledovaném období dosáhlo Hl. m. Praha (3,05 \% a kumulovaně 31,73 \%) a Plzeňský kraj (3,10 a 31,82 \%), tj. regiony s nejvyšší a třetí nejvyšší průměrnou mzdou. 
Tab. 1: Průměrná hrubá měsíční mzda v NUTS3 v letech 2002-2011 (průměr, Kč)

\begin{tabular}{|c|c|c|c|c|c|c|c|c|c|c|c|}
\hline & 2002 & 2003 & 2004 & 2005 & 2006 & 2007 & 2008 & 2009 & 2010 & 2011 & průměr \\
\hline ČR & 17295 & 18532 & 19410 & 20251 & 21582 & 23267 & 24833 & 25123 & 25279 & 24128 & 21970 \\
\hline PHA & 24833 & 26502 & 26972 & 28260 & 31173 & 33553 & 35905 & 36658 & 36124 & 33546 & 31353 \\
\hline STČ & 18075 & 19128 & 20324 & 21579 & 22811 & 25035 & 26445 & 26671 & 27001 & 25651 & 23272 \\
\hline JHČ & 16764 & 17305 & 18533 & 19333 & 20070 & 21467 & 22767 & 22951 & 23418 & 23199 & 20581 \\
\hline PLK & 17707 & 18720 & 19359 & 20253 & 21719 & 23330 & 25015 & 25176 & 25482 & 24036 & 22080 \\
\hline KVK & 16791 & 17549 & 18070 & 18583 & 20778 & 22099 & 22848 & 22926 & 22498 & 21723 & 20387 \\
\hline USK & 16874 & 18199 & 19120 & 19677 & 21399 & 22614 & 24198 & 24593 & 24874 & 23174 & 21472 \\
\hline LBK & 16895 & 17787 & 18826 & 19327 & 20645 & 22944 & 24671 & 25332 & 25089 & 23422 & 21494 \\
\hline HKK & 16575 & 17686 & 18394 & 19429 & 20087 & 21735 & 23148 & 23386 & 23950 & 22837 & 20723 \\
\hline PAK & 15885 & 17561 & 17979 & 19105 & 19943 & 21520 & 23382 & 24120 & 23537 & 22978 & 20601 \\
\hline VYS & 15571 & 16718 & 18360 & 18715 & 19988 & 21733 & 23493 & 23760 & 23944 & 22918 & 20520 \\
\hline JHM & 16486 & 18289 & 19154 & 20272 & 21583 & 23303 & 25109 & 25700 & 26223 & 24651 & 22077 \\
\hline OLK & 16470 & 17893 & 18908 & 19351 & 20923 & 22282 & 23866 & 24001 & 23997 & 22825 & 21052 \\
\hline ZLK & 16431 & 17927 & 18642 & 19786 & 20220 & 21614 & 22744 & 22572 & 23219 & 22655 & 20581 \\
\hline MSK & 16772 & 18180 & 19100 & 19838 & 20811 & 22514 & 24075 & 23873 & 24554 & 24174 & 21389 \\
\hline
\end{tabular}

Zdroj: vlastní zpracování na základě dat z Českého statistického úřadu Poznámka: Zkratky krajů jsou uvedeny dle metodiky Českého statistického úřadu: PHA=Hlavní město Praha, STČ=Středočeský kraj, JHČ=Jihočeský kraj, PLK=Plzeňský kraj, KVK=Karlovarský kraj, USK=Ústecký kraj, LBK=Liberecký kraj, HKK=Královehradecký kraj, PAK=Pardubický kraj, VYS=Kraj Vysočina, JHM=Jihomoravský kraj, OLK=Olomoucký kraj, ZLK=Zlínský kraj, MSK=Moravskoslezský kraj

Graf 1: Průměrné tempo růstu hrubé měsíčni mzdy v NUTS3 v letech 2002-2011 (\%)

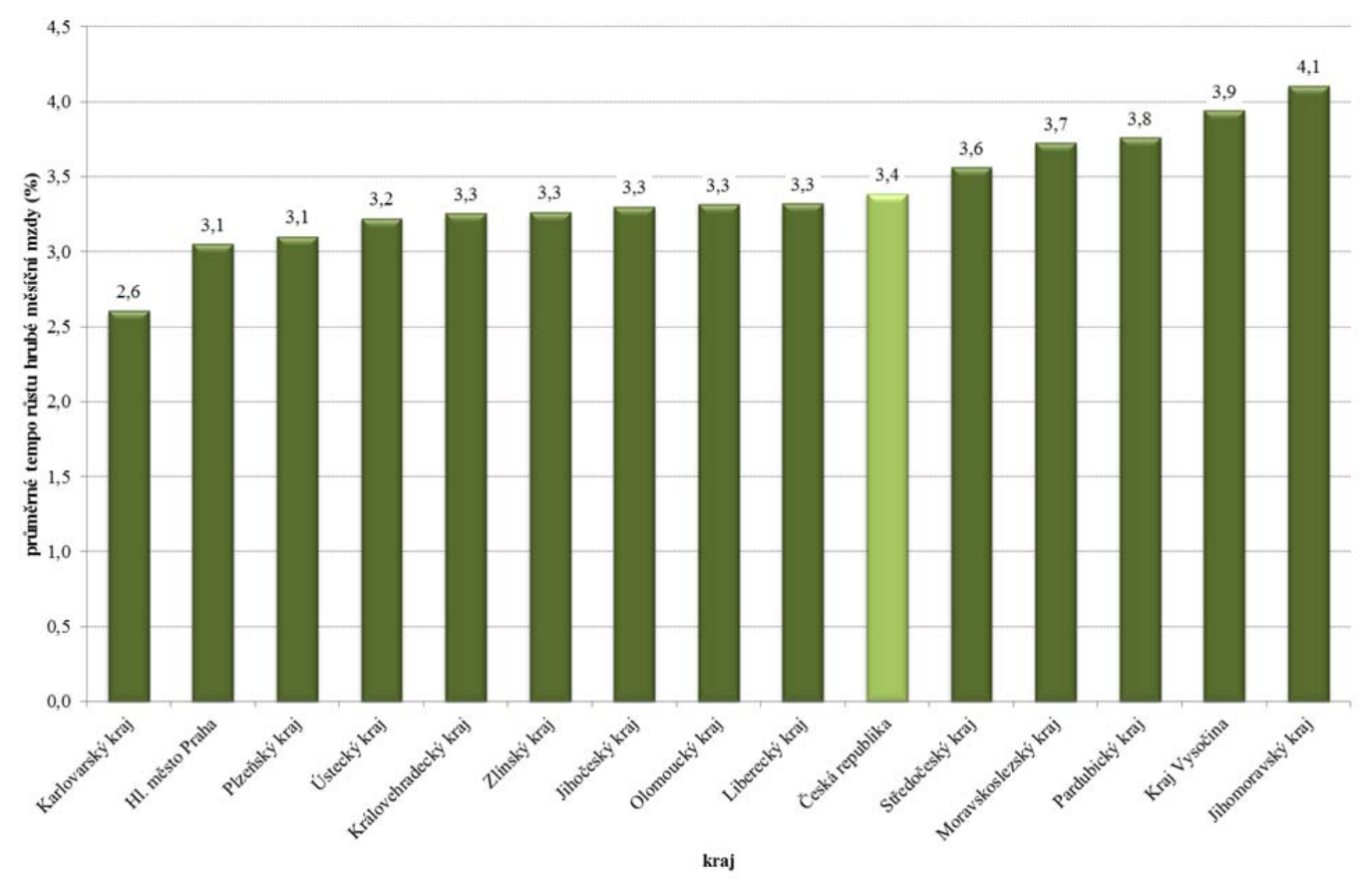

Zdroj: vlastní zpracování, vlastní výpočet

Vzhledem k tomu, že výše nominálních hrubých mezd s největší pravděpodobností poměrně výrazně ovlivňuje vývoj zaměstnanosti $\mathrm{v}$ jednotlivých regionech, jeví se nám jako zajímavé srovnání dynamiky růstu, resp. meziroční změny těchto dvou základních makroekonomických ukazatelů. Vyjdeme-li z údajů zachycených v tabulce č. 2, pak zjistíme, že jedinými dvěma kraji, které v daném období zaznamenaly průměrný meziroční nárůst míry zaměstnanosti, byly kraje Ústecký a Moravskoslezský, přičemž v případě Moravskoslezského kraje došlo mezi roky 2002 a 2011 k zvýšení 
míry zaměstnanosti o 1,90 p. b. a v Ústeckém kraji o 0,50 p. b. I přes tuto změnu, však oba výše uvedené kraje zůstávají i nadále regiony s nejnižší průměrnou mírou zaměstnanosti. V Moravskoslezském kraji dosahuje tento ukazatel výše 50,97 \% v kraji Ústeckém pak 51,79 \%. Pokud porovnáme tuto změnu s dynamikou růstu nominálních mezd, pak zjistíme, že oba kraje se pohybují spíše v druhé polovině našeho pomyslného pořadí (MSK na 8. místě a USK dokonce na 11. místě). Nejvýraznější předstih tempa růstu mezd před meziroční změnou míry zaměstnanosti tak bylo $\mathrm{v}$ daném období dosaženo $\mathrm{v}$ krajích $\mathrm{s}$ nejvyšší dynamikou růstu hrubé nominální mzdy, tj. v Pardubickém kraji, kraji Vysočina a kraji Jihomoravské.

Tab. 2: Předstih růstu hrubé měsíční mzdy před meziroční změnou míry zaměstnanosti v NUTS 3 vletech 2002-2011 (v\%)

\begin{tabular}{|l|r|r|r|}
\hline \multirow{2}{*}{} & \multicolumn{2}{|c|}{ průměrné tempo růstu/meziroční změna } & \multicolumn{2}{c|}{$\begin{array}{c}\text { předstih mezd před } \\
\text { zaměstnaností }\end{array}$} \\
\cline { 2 - 3 } & hrubá měsíční mzda & míra zaměstnanosti & 3,44 \\
\hline Česká republika & 3,39 & $-0,05$ & 3,14 \\
\hline Hl. město Praha & 3,05 & $-0,09$ & 3,59 \\
\hline Střnedočeský kraj & 3,56 & $-0,03$ & 3,41 \\
\hline Jihočeský kraj & 3,30 & $-0,11$ & 3,12 \\
\hline Plzeňský kraj & 3,10 & $-0,01$ & 2,96 \\
\hline Karlovarský kraj & 2,61 & $-0,35$ & 3,16 \\
\hline Ústecký kraj & 3,22 & 0,06 & 3,68 \\
\hline Liberecký kraj & 3,32 & $-0,36$ & 3,54 \\
\hline Královehradecký kraj & 3,26 & $-0,29$ & 3,84 \\
\hline Pardubický kraj & 3,76 & $-0,08$ & 4,12 \\
\hline Kraj Vysočina & 3,94 & $-0,18$ & 4,12 \\
\hline Jihomoravský kraj & 4,11 & $-0,01$ & 3,50 \\
\hline Olomoucký kraj & 3,32 & $-0,19$ & 3,35 \\
\hline Zlínský kraj & 3,26 & $-0,09$ & 3,49 \\
\hline Moravskoslezský kraj & 3,72 & 0,24 & \multicolumn{2}{|c|}{ Zdroj: vlastní zpracování, vlastní výpočet } \\
\hline
\end{tabular}

\section{Mzdy v Moravskoslezském kraji}

Moravskoslezský kraj je tradičně chápán jako kraj průmyslový a je spojován s hornictvím a hutnictvím. Ve skutečnosti v současné době je jeho výrobní základna silně diverzifikovaná. (Skokan K., 2002) I přes tento pozitivní vývoj můžeme ale Moravskoslezský kraj i nadále považovat za jednu z největších průmyslových oblastí v Česku, a to zejména díky významným ložiskům černého uhlí, která na sebe ve významné míře vážou nejen hutní, ale také další formy těžkého průmyslu.

Vyjdeme-li z údajů zachycených v tabulce č. 1 a v grafu č. 1, pak můžeme konstatovat, že v mzdové oblasti patř́i Moravskoslezský kraj mezi kraje s mírně podprůměrnou průměrnou hrubou měsíční mzdou (21.389 Kč ve srovnání 21.970 Kč v celé ČR) a výraznou dynamikou růstu, když průměrné tempo růstu tohoto ukazatele dosahovalo v Moravskoslezském kraji v letech 2002-2011 hodnoty 3,72 $\%$, díky čemuž hodnota mzdy kumulovaně vzrostla o 37,81 p. b., což tento region řadilo mezi první čtyři kraje s největším tempem růstu hrubých měsíčních mezd. Za významný pak můžeme označit především růst mezd v letech 2007-2008, kdy hodnota tohoto ukazatele vzrostla v průměru o 7,56 \% za rok. Budeme-li pátrat po příčinách tohoto dvouletého pozitivního obratu, pak je nalezneme zejména v rozvoji zpracovatelského průmyslu a vstupu nových investorů do jednotlivých průmyslových zón nacházejících se na území kraje. 


\section{Graf 2: Srovnání vývoje mezd v Moravskoslezském kraji dle pohlaví}

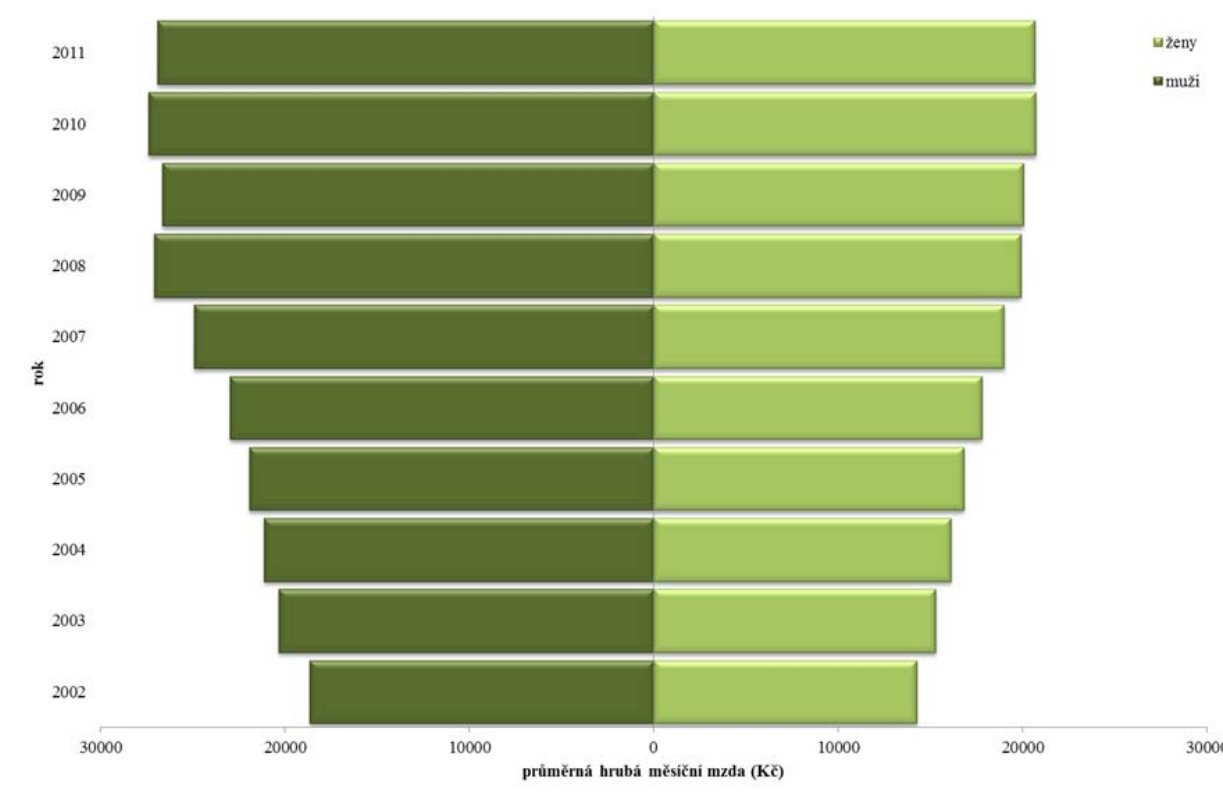

Zdroj: vlastní zpracování na základě dat z Českého statistického úradu

Z výše uvedeného je tedy zřejmé, že v př́ipadě Moravskoslezského kraje můžeme zaznamenat trvalý a poměrně výrazný růst nominálních mezd. Otázkou však zůstává, jak se tento ukazatel vyvíjel z pohledu jednotlivých skupin. Zaměříme-li se nejprve na vývoj mezd z hlediska jednotlivých pohlaví, pak zjistíme, že v Moravskoslezském kraji zaznamenaly $\mathrm{v}$ obou prrípadech nominální mzdy téměř trvalý růst, kdy v př́ípadě mužů došlo k prvním meziročnímu poklesu průměrných mezd v roce 2009 (pokles o 1,61 \%) a v př́padě obou skupin pak také v roce 2011, když mzdy mužů poklesly o 1,84 a mzdy žen o $0,27 \%$. Jak je z grafu č. 2 zřejmé, mzdové rozdíly mezi muži a ženami byly v průběhu celého námi sledovaného období poměrně výrazné a stále více se prohlubovaly. Zatímco na počátku období byla průměrná hrubá měsíční mzda mužủ 18.658 Kč a průměrná mzda žen 14.260 Kč (rozdíl $4.398 \mathrm{Kč})$, o deset let později byl tento rozdíl o téměř 42 p. b. vyšší $(26.902$ a 20.665, tj. 6.238), přičemž rozevírání těchto nůžek bylo výrazně přibrzděno po zejména v posledních třech letech ( $\mathrm{v}$ roce 2008 činil výše uvedený rozdíl dokonce 7.199 Kč, tj. nárůst o 63,69 \% oproti roku 2002).

Podíváme-li se na vývoj hrubých měsíčních mezd dle jednotlivých odvětví definovaných v rámci klasifikace CZ-NACE, pak dospějeme $\mathrm{k}$ závěru, že v letech pro něž máme $\mathrm{k}$ dispozici údaje (20052011), dosahovali v Moravskoslezském kraji nejvyšších mezd zaměstnanci v průmyslových odvětvích, kde se průměrná mzda pohybovala na úrovni $21.961 \mathrm{Kč}$, díky čemuž se tento sektor stal sektorem s nadprůměrnými hrubými mzdami (průměrná mzda v kraji 19.945 Kč). Naopak $\mathrm{s}$ dlouhodobě nejnižšími nominálními mzdami se v tomto období potýkala odvětví primárního sektoru (15.931 Kč) a odvětví velkoobchod a maloobchod; opravy a údržba motorových vozidel (16.350 Kč). 
Graf 3: Srovnání vývoje hrubých měsičních mezd vybraných odvětví v Moravskoslezském kraji v letech 2005-2011

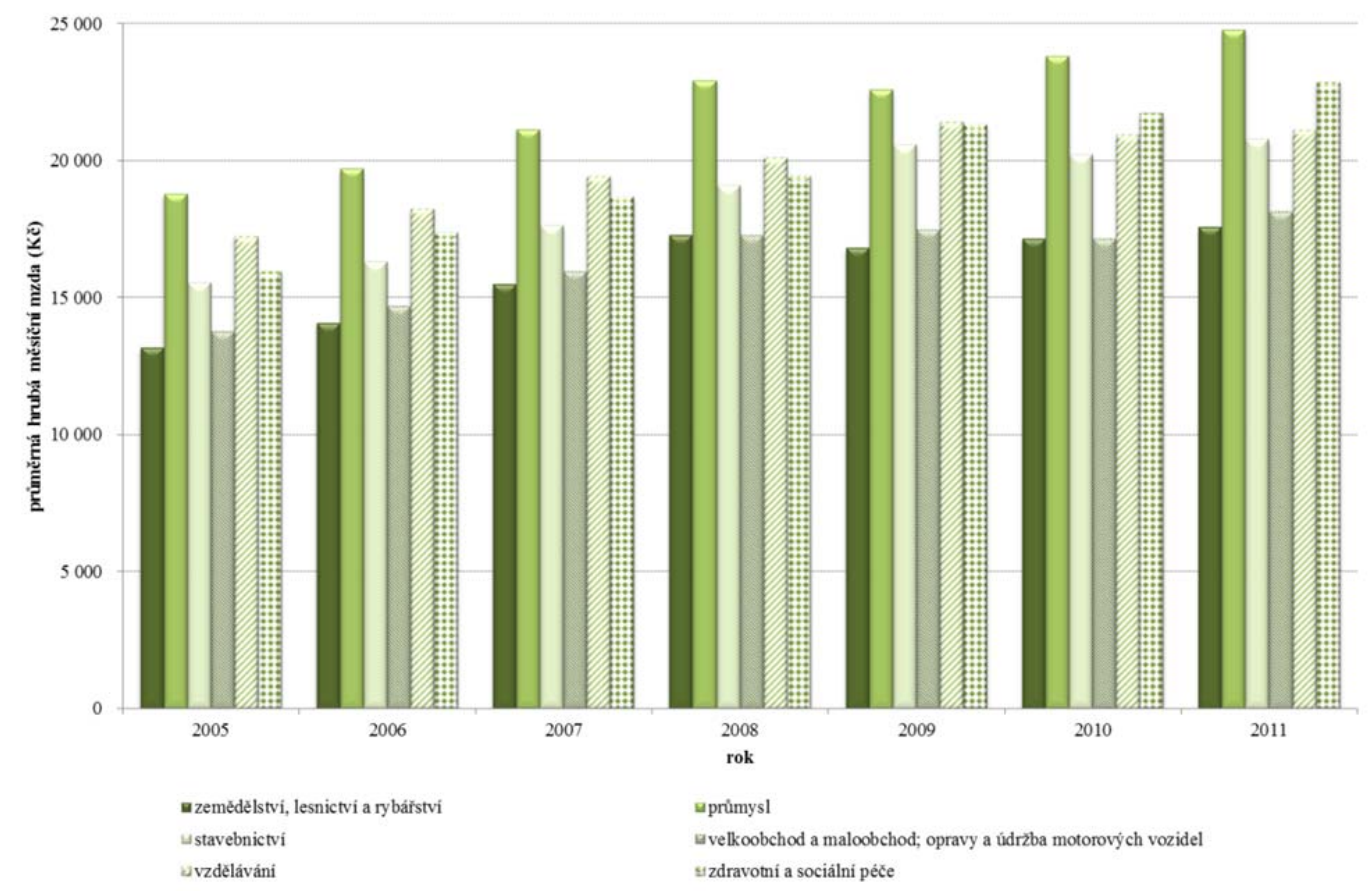

Zdroj: vlastní zpracováni na základě dat z Českého statistického úŕadu

\section{Závěr}

Mzdy jsou jedním z nejdůležitějších faktorů, které ovlivňují fungování ekonomiky země a také jsou motivující složkou člověka k práci. Člověk se rozhoduje, zda pracovat či nepracovat. Práce člověku přináší mzdu. Ale kdyby člověk nepracoval, získal by větší množství volného času. Záleží tedy na každém člověku, co je pro něj prioritou.

$\mathrm{V}$ rámci tohoto článku jsme se na problematiku mezd podívali podrobněji. Zajímal nás vývoj mezd $\mathrm{v}$ jednotlivých regionech. $\mathrm{V}$ průběhu námi analyzovaných deseti let dosahovala v České republice hrubá měsíční mzda průměrné hodnoty 21.970 Kč. Tuto částku jsme porovnali s průměrnými mzdami v jednotlivých územních jednotkách a dospěli jsme k závěru, že v letech 2002-2011 se v České republice vytvořily v podstatě pět skupiny krajů: (1) kraje s extrémně vysokou mzdou (Hl. m. Praha), (2) kraje s vysokou mzdou (Středočeský kraj), (3) kraje s průměrnou mzdou (Plzeňský a Jihomoravský kraj), (4) kraje s mírně podprůměrnou mzdou (Liberecký, Ústecký a Moravskoslezský kraj) a (5) kraje s výrazně podprůměrnou mzdou (Olomoucký, Královehradecký, Pardubický, Zlínský a Jihočeský kraj, kraj Vysočina a Karlovarský kraj). Pomocí dalších metod (např. výpočtu průměrného tempa růstu jednotlivých indikátorů) jsme analyzovali problematiku mezd podrobněji. V poslední části prŕspěvku jsme se zaměřili na detailnější analýzu průmyslově významného kraje, tedy kraje Moravskoslezského.

\section{Literatura}

[1] Český statistický úřad. Dostupné z: <www.czso.cz>.

[2] FUCHS, K., TULEJA, P. Základy ekonomie. Praha: Ekopres, 2003. ISBN 80-86119-74-2.

[3] HOLMAN, R. Ekonomie. 4. vyd. Praha: C. H. Beck, 2005. 709 s. ISBN 80-7179-891-6.

[4] NEVIMA, J., RAMÍK, J. „Application of DEA for evaluation of regional efficiency of EU regions“. In Proceedings of the 28th international conference Mathematical Methods in Economics 2010. České Budějovice: Faculty of Economics, 2010. ISBN 978-80-7394-218-2.

[5] SKOKAN, K. Industry Clusters v regionálním rozvoji. Ekonomická revue, 2002, Vol. 5, No. 2, pp 50-60. 
[6] TVRDOŇ, M. Institucionální aspekty fungování trhu práce. Politická ekonomie 2008, LVI (5), pp 621-642. ISSN 0032-3233.

Př́spěvek byl zpracován za podpory Studentské grantové soutěže SU v rámci projektu SGS/7/2012 „Vliv regionálních disparit na podnikatelské prostředi““. 